\title{
Does State Antitrust Enforcement Drive Establishment Exit?
}

\author{
Robert M. Feinberg, Thomas A. Husted, and Florian Szücs*
}

August 2013

\begin{abstract}
Previous work has shown that state-level antitrust enforcement activity may have impacts on entry and relocation behavior by U.S. firms. Significant state-level antitrust activity may be an indicator of a perceived adverse business environment and it is found to deter establishment entry, particularly for larger firms in the retail and wholesale sectors. An obvious question is whether establishment exit is affected in a symmetric way, or whether sunk costs of market entry may lead to a smaller impact in terms of the exit decisions. We first combine US Census establishment exit panel data with data for 1998-2006 on US state-level antitrust activity and other measures of state-level business activities that may affect establishment exit. We also consider establishment exit across different broad industry types -- manufacturing, retail and wholesale -- and several firm size categories. Local business cycle factors seem to be the primary driver of exit, though there is some evidence of political and antitrust determinants as well. In another approach, we examine firm-level exit decisions and the extent to which these respond to state antitrust enforcement, with some indication of antitrust enforcement effects here as well, especially in the wholesale and retail sectors.
\end{abstract}

*American University, American University, and DIW Berlin, respectively. 


\section{Introduction}

Antitrust enforcement in the U.S. at the state level has only recently been the focus of significant attention by economic and legal scholars, in part due to the increased availability of data (through the NAAG Antitrust Multistate Task Force). Feinberg and Reynolds (2010) discuss (and explain the determinants of) patterns of state antitrust filings over the past two decades, and Feinberg and Husted (2011) and Feinberg (2012) show that this enforcement, especially non-horizontal cases, may be viewed by potential entrants as a negative aspect of the state business climate. What has not been examined is whether antitrust at the state level provides impetus for establishment exit.

This paper first uses state-level data on establishment exit from the Statistics of U.S. Business to examine exit in response to state antitrust enforcement by firms within four firm size categories: 1-19 employees; 20-99 employees; 100-499 employees; and more than 500 employees. For each, differences in behavior by broad business sector are explored. We then pursue a firm-level analysis and look for antitrust effects there as well, also focusing on firm-size differences.

\section{Literature review and theoretical motivation}

There is a large literature on the determinants of business location decisions (both within and across countries), largely focused on demand and cost effects on firm decisions (see Armington and Acs (2002) and Sutaria and Hicks (2004) for reviews). Among variables considered are unemployment rates, population density, labor costs (including the degree of unionization), and area income levels, as well as expected future growth (generally measured by lagged actual growth in demand). Others have looked at broader notions of how the business climate affects location 
decisions. For example, Bartik (1988) found that state government environmental regulatory policies had small and not always statistically significant impacts on plant and small business location decisions.

While there have been a large number of empirical studies investigating the determinants of entry, far fewer have examined determinants of survival or exit of firms. In terms of theory, Ghemawat and Nalebuff (1985) derive results showing - somewhat counter-intuitively - that small firms are better able to survive demand downturns than large firms when they have comparable costs; however, where scale economies are important (as may be true in many manufacturing industries) the pattern reverses with small firms the first to exit. Turning to empirical evidence, Shapiro and Khemani (1987) find (surprisingly) that high profit industries experience more exits, as high profits attract more entrants who then displace some incumbents; they also observe that exit rates are lower where sunk costs of large plant size and related high capital requirements exist.

Dunne et al. (1988) for the period 1963-1982, find small, relatively new, firms to have the highest failure rates, though relatively more successful are firms diversifying from other manufacturing industries through new-plant construction. Phillips and Kirchhoff (1989) examine survival rates of new firms, reporting that survival chances are highest for those new firms showing growth in their early years.

Audretsch (1994), examining data (obtained from the US Small Business Administration) on more than 12,000 US manufacturing plants established in 1976, finds that establishments larger on entry had a lower chance of exit over the next 10 years as did newly-formed independent 
establishments (relative to newly-created affiliates of multi-plant firms); innovative activity by new firms had somewhat ambiguous impacts on subsequent exit, though raising survival probabilities over the long-run. Wagner (1994), in a similar study of German establishments, observes no clear link between start-up size and exit rates; he does, however, find the result noted by Phillips and Kirschhoff (1989) for the US that surviving firms are more likely to have experienced high rates of growth in their early years.

Audretsch and Mahmood (1995) involved a further look into the SBA dataset utilized in Audretsch (1994), with similar findings - they do note that improved macroeconomic conditions (proxied by the unemployment rate) leads to reduced exit rates. Kleijweg and Lever (1996) study entry and exit in Dutch manufacturing industries during the 1980s, and find that R\&D intensive industries experience reduced rates of exit. Feinberg (2010) analyzes the effect of international competition on exit rates in a large number of U.S. retail and wholesale sectors, concluding that retailers are little affected, but wholesalers do experience more exit when the dollar appreciates. Feinberg (2013) considers similar issues in manufacturing, finding that international pressures seem to lead to increased rates of smallest-firm exit, though high-tech industries avoid much of this impact. Studies of regulatory impacts on exit have tended to focus on environmental rules; a survey by Jeppesen and Folmer (2001) finds that most studies have found small impacts (in both directions), but that plant closing effects are more likely to be found, not surprisingly, in highly-polluting industries.

Why might state antitrust influence the business exit decision? While little studied in the literature, in recent years U.S. states have been increasingly aggressive in filing antitrust cases under 
both state and federal laws; in part, this may have been a response to a perception of less interest in enforcement at the federal level, or a response to the Supreme Court’s 1977 Illinois Brick case prohibiting antitrust damage recovery by indirect purchasers and, perhaps more importantly, later decisions allowing state antitrust laws which rejected that finding. ${ }^{1}$

Studies of the effects of federal antitrust on firm behavior have tended to focus on pricing effects rather than location decisions (e.g., Feinberg (1980) and Block et al. (1981)). However, in terms of the effects of state antitrust, former Deputy Assistant Attorney General Deborah Platt Majoras, quoted in Caulkins (2003, p. 685), notes that some critics claim state antitrust enforcement "adds a significant layer of uncertainty for businesses in their consideration of possible mergers and in their business conduct-uncertainty that may chill pro-competitive mergers and conduct and add significant costs.” The first study to systematically examine this question was Feinberg and Husted (2011), which found state antitrust filings limiting large firm entry and relocation; this effect, however, was limited to cases dealing with other than horizontal (cartel, bid-rigging, market allocation) conspiracies. For small firms the only impact of antitrust was that of horizontal cases and here the effect was to encourage entry.

Feinberg (2012) disaggregated that analysis to look at state antitrust impacts on several disaggregated categories of small firm entry, both by size of firm and broad industry sector, finding the smallest retail and wholesale firms to favor vigorous antitrust activity, especially enforcement

\footnotetext{
${ }^{1}$ Feinberg and Reynolds (2010) examined the political economy of state-level antitrust activity, finding determinants of state antitrust filings to be quite similar to what has been found in the literature on federal antitrust activity (for one example, see Ghosal and Gallo (2001)); case filings tend to be countercyclical and political influences play a role as well. Rather than filling in gaps in federal enforcement - substituting for declines in this activity - state antitrust filing seems more complementary to cases brought by the DOJ's Antitrust Division.
} 
targeted against cartel behavior by suppliers, the largest small-firm retailers and wholesalers (those with 100-499 employees) to be somewhat threatened by such activity, especially the more controversial non-horizontal enforcement, and no impact on small manufacturers. All of these effects, however, both positive and negative were quite small even where statistically significant.

No previous work has looked at exit effects of state variation in antitrust enforcement. On the one hand, one might expect to see symmetric impacts on entry and exit. But on the other, there is the possibility that adverse business shocks that discourage entry might only lead to exit if they are perceived as large enough to overcome the sunk/fixed costs that were associated with entry in the first place. Kneller and McGowan (2012), in a study of impacts of tax increases in OECD countries, find that new entry is discouraged but existing firms are not induced to exit; they refer to studies finding such hysteresis in the effects of other policy changes (e.g., exchange rate shocks and export decisions).

Before moving to the statistical analysis, two caveats should be kept in mind. The first is that the level of aggregation employed in our state-level results (2-digit NAICS categories and state-level averages) may be too great to capture motivations of heterogeneous firms; this is remedied in our firm-level analysis to follow. However, at least equally important, Headd (2003) notes that business closure ("exit") may not always reflect "failure"; he found that about a third of closed businesses regarded themselves as successful at closure. This suggests that the exit decisions by small firms may be driven in large part by idiosyncratic individual explanations for why firms choose to shut down which may not be well captured by the explanatory variables utilized in this study. 


\section{Methodology and Data}

As our focus is on state-level antitrust enforcement effects, we first analyze determinants of establishment exit across 50 states over 9 years (1998-2006). These do not necessarily represent the departure of a firm, and may simply involve the closing of a particular factory, wholesale facility or retail outlet. Exit data (on annual establishment deaths) come from the Statistics of US Business, a Census product produced for the US Small Business Administration. The analysis is performed separately for firms with greater than and less than 500 employees, as well as for 9 sub-categories of small firms -- 1-19, 20-99, and 100-499 employee firms -- in each of the manufacturing, wholesale and retail sectors. ${ }^{2}$

Following the previous literature, business exit decisions are expected to depend on actual and anticipated movements in local demand and costs, as well as proxies for local amenities and political factors. We will include one-year lagged measures of state-level economic data (unemployment and unionization rates, and annual rate of growth in GSP as an indicator of future demand growth prospects), political factors (political party of the governor and attorney general), and state government tax and expenditure characteristics (the size of state and local income and corporate taxes relative to state GSP and the relative size of government spending).

GSP is measured in millions of chained 2000 dollars, and sourced from the Bureau of Economic Analysis of the U.S. Department of Commerce. Economic activity in the state is proxied

\footnotetext{
${ }^{2}$ The employment size of exit is determined by size of firm, not size of establishment; e.g., the closing of a Starbucks in a state would be classified as large-firm exit. Only firms with at least one salaried employee are included in the analysis.
} 
by the annual average state unemployment rate from the Bureau of Labor Statistics. To investigate whether firms look to the political affiliation of the state's leader as a predictor of future policies which may impact their future profits, a dummy variable will be included indicating whether the state’s governor was a Republican during a particular year. States with larger state and local government spending relative to the size of their economies may imply less exit if this is viewed as translating into more amenities or better infrastructure for firms or their workers; ${ }^{3}$ this variable is calculated by using data from the Census Bureau's State Government Finances annual survey.

The state's income and corporate tax burden is obtained from the Census of Governments. The percentage of a state's private sector workers that are covered by union contracts (as described in Hirsch and Macpherson (2003)) is included as a proxy for cost differences across states. To account for the possibility that the current market structure in a state may create barriers to establishment survival, we incorporate a (rough) proxy for the role of relatively large firms by including the percentage of a state's workers employed in firms with greater than 500 employees. As previous studies (especially Dunne et al. (1988) and Brown et al. (2006)) have identified "churning" as a prominent feature of many industries - with firms constantly entering and exiting we also, for robustness, include in some specifications an entry-rate variable in explaining exit rates. (A modest effort at dealing with endogeneity concerns is to measure the entry-rate variable at a higher level of aggregation than the exit-rate variable being explained.)

The primary contribution in this study, however, is to add to the analysis data on state-level antitrust litigation that have been developed from a database provided by the National Association of

\footnotetext{
${ }^{3}$ Of course, this may also relate to a higher tax burden but that is controlled for separately.
} 
Attorneys General (NAAG). All U.S. states have some form of antitrust statutes on their books and the further ability to bring actions under the federal antitrust laws. We identify the number of antitrust cases filed by states as a "lead plaintiff" as our measure of antitrust activity. ${ }^{4}$

The number of antitrust cases that are filed per year by individual states has varied considerably, both over time and across states. The total number of state antitrust cases filed over the full NAAG database period ranged from as low as 12 cases in 1990 to as high as 31 cases in 1994. Over half of state antitrust enforcement was undertaken by four states: New York, Florida, Texas, and California. In contrast, seven states filed zero antitrust cases during this time period. About half of state cases filed involved horizontal conspiracy (mostly bid-rigging or price-fixing) charges; about a third of them involved merger reviews.

To normalize for the size of a state's economy, in the statistical analysis to follow, litigation is measured relative to GSP. This normalization makes quite a difference in interpreting the aggressiveness of state antitrust enforcement; for example, while New York, California, and Florida are the three top states in terms of total cases filed over the 1998-2005 period studied in this report, only New York (tied for $7^{\text {th }}$ place) is among the top ten states in case filings relative to the size of their economies - the top five states in terms of case filings per dollar of GSP are Maine, Vermont (these two tied for $4^{\text {th }}$ place in total cases filed), Utah, Alaska, and West Virginia.

We also distinguish antitrust effects by type of case; investigations against cartel-type activity are the least controversial of government actions in the antitrust area, and aggressive

\footnotetext{
${ }^{4}$ In about $15 \%$ of cases filed there are multiple "lead plaintiffs," and in a smaller percentage of cases other states joined in at a later stage, including at the settlement stage.
} 
enforcement activity of this kind may not be viewed unfavorably by businesses that within a state (they may in fact be viewed as a desirable element of the state's law enforcement regime, especially by smaller firms). A measure of antitrust cases excluding horizontal conspiracy cases (relative to GSP) may, however, have a somewhat stronger impact on exit. ${ }^{5}$ The estimation assumes that the current perception of the strength of the state's antitrust enforcement is a function of the most recent past case filings (relative to the size of the state economy) and the political party of the state's attorney general. ${ }^{6}$

Not included in the regression analysis are measures of environmental (or other) regulatory efforts at the state level, implicitly assuming that these did not vary over the (relatively short) time period examined - allowing their impacts to be captured by state fixed effects. ${ }^{7}$ It must be acknowledged however that any effect observed of state antitrust enforcement on firm exit may in part reflect a broader perception by business of changes in the legal and political environment within the state over the time period considered.

As mentioned briefly in the introduction, we corroborate the analysis described above on the firm-level to better capture the individual exit motives of heterogeneous firms. From the Thomson Worldscope database, we compile a dataset of 5257 US firms (assigned to states based on their

\footnotetext{
${ }^{5}$ By "horizontal" cases, we are referring to ones targeting actions among firms in the same industry who are attempting to collude or otherwise limit competition among themselves; economists generally agree that such efforts at collusion are welfare-reducing and support antitrust actions to limit them. Vertical cases involve firms interacting with others in a buyer or seller relationship (e.g., wholesalers dealing with retailers or manufacturers); these cases are less widely supported by economists as there may be both benefits (perhaps reduced transactions costs among firms) and costs (reduced competition from firms left out of the vertical arrangement) to the economy from vertical agreements.

${ }^{6}$ Given that most states elect governors and attorneys general separately, the correlation coefficient between dummy variables for each being a Republican is not especially high: +0.25 . In previous work explaining entry, past antitrust case filings were included but these generally did not have a statistically significant effect.

${ }^{7}$ While various indexes of state regulatory burden exist, these are not available annually for the time period considered in this study.
} 
headquarters location) active in 1997 in the manufacturing, retailing or wholesaling sectors of the economy. About a quarter of these firms eventually exit the market during the sample period. We then employ a panel probit approach to explain a firm's exit decision in years 1998 through 2006 dependent on the state-level economic, political, and antitrust variables used in the analysis above, plus a firm size and lagged firm profitability measure. In line with the industry-level regressions we distinguish small and large firms by splitting the sample in firms with less and more than 500 employees.

Some of the exits observed in the firm-level data can be attributed to mergers, takeovers or similar transactions. Since these are not the types of market exits our analysis focuses on, we try to control for them by cross-checking exiting firms with the Thomson 'Worldwide Mergers \& Acquisitions' database, which contains entries for all major ( $>\$ 1$ million) M\&A transactions. We then recode all firms that were the target of a merger during the year of their exit or the year before to non-exiting, that is, we keep them in the sample but don’t count them as exiting. ${ }^{8}$ This decreases the number of exiting firms in the sample to 987.

\section{Descriptive Statistics}

Descriptive statistics for the variables of interest are presented in Table 1. Industry-level exit rates (panel 1 of table 1) vary quite a bit across industry and firm size categories. The highest average annual rates of state-level establishment exit (at over 12 percent annually) are by the smallest retail firms, while the lowest rates (4.4 percent on average over the fifty states and sampled

\footnotetext{
${ }^{8}$ We repeat all regressions in two alternative samples where we i) keep all exiting firms (i.e. employ a more liberal definition of exits) or ii) remove all firm exits after any kind of acquisition (many of these minor asset purchases) in the previous or current year (i.e. employ a stricter definition of exits) and obtain very similar results, which are not reported.
} 
time period) are by small (20-99 employee) manufacturing firms. Within these categories we see substantial variation across states as well. On the firm-level (panel 2 of table 1), exit rates are fairly similar for small and large firms in manufacturing (3.3 - 3.9\%), but differ substantially for retail (small firms have a yearly exit rate of 6.4\%, large firms only 3.4\%) and wholesale (4.9\% versus $2.7 \%)$.

As for the explanatory variables (panel 3 of table 1), states grew at an average annual rate of 2.85 percent over the 1998-2006 period, with an average unemployment rate of 4.66 percent, and with $8.5 \%$ of their private employees covered by union contracts. The state government budget share of Gross State Product averaged 13.67 percent, but varied between 7.6 and 29.6 percent. Their income and corporate tax share varied from zero to 5.24 percent, averaging 2.44 percent. The employment share of large firms varied quite a bit, from 27 (Kansas in 1999) to 57 percent (South Carolina in 2001). Republicans served as governors a little more than half the time, though as Attorney General only about one-third of the time. Antitrust cases filed per trillion dollars of GSP varied from zero to 4.57, with horizontal (anti-cartel or price-fixing) cases representing about 30 percent of these. ${ }^{9}$ The average profitability (defined as return - net income - on assets) in the firmlevel sample is $1.71 \%$ and firms on average have sales of $\$ 2$ billion.

\section{Industry-Level Analysis}

To start with, we report results explaining small and large firm establishment exit (the dividing line at 500 employees), separately for each of the three sectors - manufacturing, wholesale,

\footnotetext{
${ }^{9}$ In about 70 percent of state antitrust cases, there was some federal government involvement. In results not presented here we control for a differential impact of these cases.
} 
and retail. Estimating OLS models with fixed industry effects, ${ }^{10}$ we see in Table 2 that union coverage and tax rates at the state level generally seem to increase exit rates, while growth in state GSP has the opposite effect. Other control variables have more mixed impacts though, where statistically significant, Republican governors and/or Attorneys General are associated with lower exit rates. The antitrust enforcement effects on exit rates are less clear; we examine horizontal and other (merger, monopolization, vertical restrictions) antitrust case filings separately and what emerges is no impact in the wholesale and retail sectors, and no effect of horizontal cases, but significant effects of other types of state antitrust enforcement in manufacturing. The direction of these effects differs by firm size - large firms seem to respond to enhanced antitrust enforcement through reduced exit, while small firms have the opposite effect. Much of local antitrust enforcement is directed at small firms so these results may not be surprising.

As noted earlier, exit patterns in an industry may be heavily influenced by the nature of entry - on the one hand high rates of entry provide a large pool of new firms many of which will likely exit, but on the other high rates of entry can signal strong future growth and suggest less exit (in the near term at least). As discussed in Feinberg and Husted (2011) and Feinberg (2012) entry itself is likely determined by many of the same variables included in Table 2; therefore in Table 3, we include as explanatory variables just entry rates (for the entire sector, not broken down by size) and the political and antitrust variables of greatest interest here. Generally, the results for these variables are similar to what was found in Table 2, with the strongest effect of state antitrust enforcement

\footnotetext{
${ }^{10}$ Hausman tests generally support the use of fixed rather than random effects (though the variables of primary interest seem to perform similarly in random effect models). Preliminary examination of Tobit models (which deal with the fact that exit rates are constrained to be non-negative) suggests similar findings to what are reported here.
} 
again being non-cartel cases reducing exit rates by large manufacturing firms and increasing them for small manufacturers, though large wholesalers are now seen to have reduced exit rates as well.

Whether these patterns continue to hold as the sample is disaggregated by size and industry group categories of small firms is what is dealt with next. For each of the manufacturing, retail and wholesale sectors, we examined the determinants of entry rates in the three firm employment-size categories: 1-19, 20-99, 100-499. These are reported on in Tables 4, 5, and 6. For each, the full specification of Table 2 and the “entry plus political/antitrust variable” specification of Table 3 are considered.

We continue to see (with one exception out of the 9 size/sector categories) that exit is reduced by GSP growth. And, where statistically significant (only for the smallest manufacturers and wholesalers), union influence seems to promote exit. Again, with few exceptions, higher state tax rates are associated with greater establishment exit. With one exception (the smallest manufacturers), entry rates and exit rates tend to move together (supporting the "churning” view of establishment births and deaths). Especially in the disaggregated results, the impact of local economic conditions on exit seem less important for manufacturing - not surprising given their more national and international sales focus. After disaggregating by size, small retail exit is unaffected by political affiliation of the governor and/or attorney general.

Turning to the effects of the antitrust variables on disaggregated small firm exit, manufacturers with fewer than 100 employees show increasing exit in response to the morecontroversial non-horizontal enforcement (and those between 20 and 99 employees increase exit in 
response to horizontal enforcement as well). In contrast, larger (100-499 employee) retailers surprisingly -- show reduced exit in response to these cases, and there is little impact on small wholesalers (when disaggregated by size category). For the most part these effects hold both for cases filed jointly with the federal government and others; these results are not presented here, and more extensive treatment of the role of federal involvement - which may be a proxy for the importance of the case - is a task for future research.

\section{Firm-Level Analysis}

We now turn to the analysis of the firm-level sample (via an unbalanced panel probit approach, with random firm effects ${ }^{11}$ ). Splitting the sample at the 500-employee level, we examine the impact of state-level antitrust enforcement on small and large firm exit in Tables 7, 8, and 9. A few common results: with only the exception of small manufacturers, greater profitability seems to imply (as one might expect) reduced likelihood of exit, and there is little indication that firm size (within each of the large and small size categories) correlates with the exit decision. Turning to the state-level economic variables, somewhat surprisingly we find greater unemployment rates, state and local tax rates, and rates of unionization - where significant - to reduce exit. The government share of the state economy seems to increase exit. We find limited consistent effects of political party in these firm-level results.

Turning to the antitrust enforcement effects, we see no impact on manufacturers - who (selling across state borders) would most likely be more concerned with federal antitrust

\footnotetext{
${ }^{11}$ While we use fixed state effects in the earlier analysis, in this set of results fixed firm effects cannot be applied. That approach would require intra-group variation in the dependent variable within each group of observations, i.e. for each firm; however, for those firms that do not exit over the sample period (1998-2006) their dependent variable (exit) is zero for each year and thus they would be dropped from estimation with fixed-effects.
} 
enforcement. Large retailers increase exit in response to horizontal enforcement, reduce exit in response to others (perhaps due to much of state-level horizontal enforcement being aimed at local retailers, with monopolization/vertical restriction/merger cases being aimed at manufacturers). Wholesalers seem to reduce exit in response to horizontal enforcement. All of these antitrust effects are largely driven by state cases with federal involvement (as seen in results not presented here).

\section{Conclusions}

In attempting to understand the forces influencing establishment exit, macroeconomic forces and the local business climate are clearly important. However, in addition to tax and political affiliation of elected officials, state antitrust enforcement may have effects worth consideration. The results of this paper suggest that state-level antitrust (even when coordinated with the federal government) plays a fairly minor role in the exit decision of firms; if anything, vigorous enforcement of anti-cartel laws may be seen as a positive aspect, especially by larger firms, in reducing establishment deaths. 


\section{References}

Acs, Zoltan J. and David B. Audretsch, "Small Firm Entry in US Manufacturing,” Economica (1989), pp. 255-265.

Armington, Catherine and Zoltan J. Acs, “The Determinants of Regional Variation in New Firm Formation,” Regional Studies, Vol. 36, No. 1, 2002, pp. 33-45.

Audretsch, David B., "Business Survival and the Decision to Exit,” International Journal of the Economics of Business (1994): 125-137.

Audretsch, David B. and Talat Mahmood, "New Firm Survival: New Results Using a Hazard Function,” Review of Economics and Statistics (1995): 97-103.

Bartik, Timothy J., "The Effects of Environmental Regulation on Business Location in the United States,” Growth and Change Vol. 19 (Summer 1988), pp. 22-44.

Block, Michael K., Frederick C. Nold, and J. Gregory Sidak, “The Deterrent Effect of Antitrust Enforcement,” Journal of Political Economy Vol. 89, No. 3 (June 1981), pp. 429-445.

Bresnahan, Timothy F. and Peter C. Reiss, "Entry and Competition in Concentrated Markets," Journal of Political Economy Vol. 99 (1991), pp. 977-1009.

Brown, Clair, John Haltiwanger, and Julia Lane, Economic Turbulence: Is a Volatile Economy Good for America? University of Chicago Press, 2006.

Buenstorf, Guido, "Evolution on the Shoulders of Giants: Entrepreneurship and Firm Survival in the German Laser Industry,” Review of Industrial Organization (2007): 179-202.

Calkins, Stephen, “Perspectives on State and Federal Antitrust Enforcement,” Duke Law Journal 53 (2003), pp. 673-735.

Dunne, Timothy; Mark Roberts; and Larry Samuelson, "Patterns of Firm Entry and Exit in U.S. Manufacturing Industries,” Rand Journal of Economics (1988), Vol. 19, pp. 495-515.

Feinberg, Robert M., "Antitrust Enforcement and Subsequent Price Behavior," Review of Economics and Statistics, Vol. 62, November 1980, pp. 609-612.

Feinberg, Robert M., “Do International Shocks Affect Small Wholesalers and Retailers?” Review of World Economics (2010): 323-33.

Feinberg, Robert M., "State Antitrust Enforcement in the US and Implications for Small Business Entry and Relocation,” Working Paper, 2012. 
Feinberg, Robert M., "International Competition and Small-Firm Exit in US Manufacturing,” Eastern Economic Journal, Vol. 39, No. 3, June 2013, pp. 402-414.

Feinberg, Robert M. and Thomas A. Husted, "Patterns of Establishment Entry and State-Level Antitrust,” Journal of Competition Law and Economics, Vol. 7, No. 4, December 2011, pp. 813-825.

Feinberg, Robert M. and Kara M. Reynolds, “The Determinants of State-Level Antitrust Activity,” Review of Industrial Organization, Vol. 37, No. 3, November 2010, pp. 179-196.

Ghemawat, Pankaj and Barry Nalebuff, “Exit,” RAND Journal of Economics (1985): 63-71.

Ghosal, Vivek and Joseph Gallo, “The Cyclical Behavior of the Department of Justice's Antitrust Enforcement Activity,” International Journal of Industrial Organization (2001), Vol. 19, pp. 27-54.

Headd, Brian, “Redefining Business Success: Distinguishing Between Closure and Failure,” Small Business Economics (2003): 51-61.

Hirsch, Barry T. and David A. Macpherson, "Union Membership and Coverage Database from the Current Population Survey: Note," Industrial and Labor Relations Review, Vol. 56, No. 2, January 2003, pp. 349-54.

Jeppesen, Tim and Henk Folmer, “The Confusing Relationship between Environmental Policy and Location Behaviour of Firms: A Methodological Review of Selected Case Studies,” The Annals of Regional Science (2001), Vol. 35, No. 4, pp. 523-546.

Kleijweg, Aad J.M. and Marcel H.C. Lever, "Entry and Exit in Dutch Manufacturing Industries,” Review of Industrial Organization (1996): 375-382.

Kneller, Richard and Danny McGowan, "Tax Policy and Firm Entry and Exit Dynamics: Evidence from OECD Countries,” Bangor Business School Research Paper No. 12/006, July 2012.

Phillips, Bruce D. and Bruce A. Kirchhoff, "Formation, Growth and Survival: Small Firm Dynamics in the US Economy,” Small Business Economics (1989): 65-74.

Shapiro, Daniel, “Entry, Exit, and the Theory of Multinational Corporations.” in The Multinational Corporation in the 1980s . Edited By David B. Audretsch and Charles P. Kindleberger, Cambridge: MIT Press, 1983. 103-121.

Shapiro, Daniel and R.S. Khemani, “The Determinants of Entry and Exit Reconsidered.” International Journal of Industrial Organization (1987): 15-26.

Sutaria, Vinod and Donald A. Hicks, "New Firm Formation: Dynamics and Determinants,” The Annals of Regional Science, 38 (2004), pp. 241-262. 
Wagner, Joachim, “The Post-Entry Performance of New Small Firms in German Manufacturing Industries,” Journal of Industrial Economics (1994): 141-154. 
Table 1: Summary Statistics (50 states, 1998-2006)

\begin{tabular}{|c|c|c|}
\hline Dependent Variables - Industry level & Mean & Std. Dev. \\
\hline Exit Rate, Small Manufacturing (under 500 employees) & 8.73 & 1.97 \\
\hline Exit Rate, Large Manufacturing (over 500 employees) & 5.86 & 2.05 \\
\hline Exit Rate, Small Retail (under 500 employees) & 10.07 & 2.25 \\
\hline Exit Rate, Large Retail (over 500 employees) & 6.36 & 2.36 \\
\hline Exit Rate, Small Wholesale (under 500 employees) & 9.14 & 1.63 \\
\hline Exit Rate, Large Wholesale (over 500 employees) & 9.13 & 2.58 \\
\hline Exit Rate, Small Manufacturing (1-19 employees) & 10.87 & 1.64 \\
\hline Exit Rate, Small Manufacturing (20-99 employees) & 4.41 & 1.44 \\
\hline Exit Rate, Small Manufacturing (100-499 employees) & 4.78 & 2.26 \\
\hline Exit Rate, Small Retail (1-19 employees) & 12.13 & 1.57 \\
\hline Exit Rate, Small Retail (20-99 employees) & 5.57 & 2.26 \\
\hline Exit Rate, Small Retail (100-499 employees) & 5.97 & 2.98 \\
\hline Exit Rate, Small Wholesale (1-19 employees) & 10.75 & 1.60 \\
\hline Exit Rate, Small Wholesale (20-99 employees) & 4.73 & 1.92 \\
\hline Exit Rate, Small Wholesale (100-499 employees) & 5.39 & 2.31 \\
\hline Dependent Variables - Firm level & Mean & Std. Dev. \\
\hline Exit Rate, Small Manufacturing (under 500 employees) & 3.89 & 19.34 \\
\hline Exit Rate, Large Manufacturing (over 500 employees) & 3.34 & 17.97 \\
\hline Exit Rate, Small Retail (under 500 employees) & 6.44 & 24.56 \\
\hline Exit Rate, Large Retail (over 500 employees) & 3.44 & 18.24 \\
\hline Exit Rate, Small Wholesale (under 500 employees) & 4.92 & 21.64 \\
\hline Exit Rate, Large Wholesale (over 500 employees) & 2.66 & 16.10 \\
\hline Independent Variables & Mean & Std. Dev. \\
\hline Entry Rate, Manufacturing & 7.57 & 1.86 \\
\hline Entry Rate, Retail & 9.61 & 1.77 \\
\hline Entry Rate, Wholesale & 8.57 & 1.88 \\
\hline Annual Rate of GSP Growth & 2.90 & 2.49 \\
\hline Unemployment Rate & 4.69 & 1.14 \\
\hline$\%$ of workers in firms with over 500 employees & 0.46 & 0.06 \\
\hline Private Sector Union Coverage Rate & 8.62 & 3.97 \\
\hline Taxes as \% of GSP & 2.43 & 1.20 \\
\hline Government Spending as \% of GSP & 13.45 & 3.61 \\
\hline GOP Governor & .56 & .50 \\
\hline GOP Attorney General & .35 & .48 \\
\hline (Antitrust Cases - Horizontal Cases)/GSP & 3.29 & 9.75 \\
\hline Horizontal Cases/GSP & 1.39 & 4.81 \\
\hline (Antitrust Cases - Horizontal Cases)/GSP - with federal & 2.71 & 8.79 \\
\hline Horizontal Cases/GSP - with federal & 0.99 & 3.92 \\
\hline Firm-level Profitability (\%) & 1.71 & 10.49 \\
\hline Firm-level Sales (billion \$) & 2.01 & 9.69 \\
\hline
\end{tabular}


Table 2: Horizontal and Non-horizontal Antitrust Cases

Fixed Effects Coefficients (t-statistics)

Dependent Variable=Establishment Gross Exit Rates, by Type and Size

\begin{tabular}{|c|c|c|c|c|c|c|}
\hline Variable & $\begin{array}{l}\text { Manuf- } \\
\text { Small }\end{array}$ & $\begin{array}{l}\text { Manuf- } \\
\text { Large }\end{array}$ & Retail-Small & Retail-Large & $\begin{array}{l}\text { Wholesale- } \\
\text { Small }\end{array}$ & $\begin{array}{l}\text { Wholesale- } \\
\text { Large }\end{array}$ \\
\hline Intercept & $\begin{array}{l}11.71 \\
(7.24)\end{array}$ & $\begin{array}{l}0.83 \\
(0.40)\end{array}$ & $\begin{array}{l}16.06 \\
(8.06)\end{array}$ & $\begin{array}{l}4.07 \\
(1.62)\end{array}$ & $\begin{array}{l}10.48 \\
(8.76)\end{array}$ & $\begin{array}{l}9.62 \\
(3.50)\end{array}$ \\
\hline $\begin{array}{l}\text { Annual Rate of GSP } \\
\text { Growth }\end{array}$ & $\begin{array}{l}-0.07 \\
(2.25)\end{array}$ & $\begin{array}{l}-0.20 \\
(4.79)\end{array}$ & $\begin{array}{l}-0.07 \\
(1.77)\end{array}$ & $\begin{array}{l}-0.10 \\
(1.95)\end{array}$ & $\begin{array}{l}-0.13 \\
(5.67)\end{array}$ & $\begin{array}{l}-0.36 \\
(6.52)\end{array}$ \\
\hline $\begin{array}{l}\text { Unemployment } \\
\text { Rate }\end{array}$ & $\begin{array}{l}0.56 \\
(5.59)\end{array}$ & $\begin{array}{l}-0.36 \\
(2.80)\end{array}$ & $\begin{array}{l}0.68 \\
(5.55)\end{array}$ & $\begin{array}{l}-0.79 \\
(5.11) \\
\end{array}$ & $\begin{array}{l}-0.003 \\
(0.05) \\
\end{array}$ & $\begin{array}{l}-0.67 \\
(3.96) \\
\end{array}$ \\
\hline $\begin{array}{l}\text { Private Sector } \\
\text { Union Coverage } \\
\text { Rate }\end{array}$ & $\begin{array}{l}0.38 \\
(4.78)\end{array}$ & $\begin{array}{l}-0.08 \\
(0.81)\end{array}$ & $\begin{array}{l}0.50 \\
(5.12)\end{array}$ & $\begin{array}{l}-0.39 \\
(3.14)\end{array}$ & $\begin{array}{l}0.15 \\
(2.63)\end{array}$ & $\begin{array}{l}0.31 \\
(2.30)\end{array}$ \\
\hline $\begin{array}{l}\text { \% of workers in } \\
\text { firms with over } 500 \\
\text { employees }\end{array}$ & $\begin{array}{l}0.07 \\
(0.07)\end{array}$ & $\begin{array}{l}-2.56 \\
(1.92)\end{array}$ & $\begin{array}{l}1.05 \\
(0.82)\end{array}$ & $\begin{array}{l}-4.95 \\
(3.07)\end{array}$ & $\begin{array}{l}0.41 \\
(0.53)\end{array}$ & $\begin{array}{l}-2.61 \\
(1.48)\end{array}$ \\
\hline Taxes as $\%$ of GSP & $\begin{array}{l}-0.95 \\
(3.54)\end{array}$ & $\begin{array}{l}1.31 \\
(3.78)\end{array}$ & $\begin{array}{l}-2.46 \\
(7.42)\end{array}$ & $\begin{array}{l}2.81 \\
(6.73)\end{array}$ & $\begin{array}{l}0.42 \\
(2.09)\end{array}$ & $\begin{array}{l}0.88 \\
(1.93)\end{array}$ \\
\hline $\begin{array}{l}\text { Government } \\
\text { Spending as \% of } \\
\text { GSP }\end{array}$ & $\begin{array}{l}-0.45 \\
(7.77)\end{array}$ & $\begin{array}{l}0.46 \\
(6.12)\end{array}$ & $\begin{array}{l}-0.56 \\
(7.77)\end{array}$ & $\begin{array}{l}0.37 \\
(4.06)\end{array}$ & $\begin{array}{l}-0.24 \\
(5.47)\end{array}$ & $\begin{array}{l}0.01 \\
(0.07)\end{array}$ \\
\hline GOP Governor & $\begin{array}{l}0.04 \\
(0.24)\end{array}$ & $\begin{array}{l}-0.39 \\
(1.72)\end{array}$ & $\begin{array}{l}0.20 \\
(0.89)\end{array}$ & $\begin{array}{l}-0.20 \\
(0.73)\end{array}$ & $\begin{array}{l}-0.23 \\
(1.76)\end{array}$ & $\begin{array}{l}-0.01 \\
(0.02)\end{array}$ \\
\hline $\begin{array}{l}\text { GOP Attorney } \\
\text { General }\end{array}$ & $\begin{array}{l}-0.62 \\
(2.54)\end{array}$ & $\begin{array}{l}0.002 \\
(0.01)\end{array}$ & $\begin{array}{l}-0.56 \\
(1.85)\end{array}$ & $\begin{array}{l}0.28 \\
(0.75)\end{array}$ & $\begin{array}{l}-0.28 \\
(1.56)\end{array}$ & $\begin{array}{l}0.15 \\
(0.36)\end{array}$ \\
\hline $\begin{array}{l}\text { (Antitrust Cases - } \\
\text { Horizontal } \\
\text { Cases)/GSP }\end{array}$ & $\begin{array}{l}0.02 \\
(2.82)\end{array}$ & $\begin{array}{l}-0.02 \\
(1.83)\end{array}$ & $\begin{array}{l}0.004 \\
(0.33)\end{array}$ & $\begin{array}{l}-0.01 \\
(0.77)\end{array}$ & $\begin{array}{l}-0.001 \\
(0.22)\end{array}$ & $\begin{array}{l}-0.02 \\
(1.42)\end{array}$ \\
\hline $\begin{array}{l}\text { (Horizontal } \\
\text { Cases)/GSP }\end{array}$ & $\begin{array}{l}-0.002 \\
(0.13)\end{array}$ & $\begin{array}{l}-0.02 \\
(1.16)\end{array}$ & $\begin{array}{l}0.002 \\
(0.11)\end{array}$ & $\begin{array}{l}-0.01 \\
(0.36)\end{array}$ & $\begin{array}{l}0.003 \\
(0.22)\end{array}$ & $\begin{array}{l}-0.01 \\
(0.31)\end{array}$ \\
\hline $\mathrm{R}^{2}$ & 0.32 & 0.25 & 0.34 & 0.24 & 0.26 & 0.18 \\
\hline
\end{tabular}


Table 3: Horizontal and Non-horizontal Antitrust Cases with Entry Rate Fixed Effects Coefficients (t-statistics) Dependent Variable=Establishment Gross Exit Rates, by Type and Size

\begin{tabular}{|c|c|c|c|c|c|c|}
\hline Variable & Manuf-Small & Manuf-Large & Retail-Small & Retail-Large & $\begin{array}{l}\text { Wholesale- } \\
\text { Small }\end{array}$ & $\begin{array}{l}\text { Wholesale- } \\
\text { Large }\end{array}$ \\
\hline Intercept & $\begin{array}{l}11.35 \\
(14.22)\end{array}$ & $\begin{array}{l}7.02 \\
(7.09)\end{array}$ & $\begin{array}{l}20.73 \\
(25.29)\end{array}$ & $\begin{array}{l}-8.58 \\
(9.93)\end{array}$ & $\begin{array}{l}8.93 \\
(18.49)\end{array}$ & $\begin{array}{l}5.09 \\
(4.91)\end{array}$ \\
\hline Entry Rate & $\begin{array}{l}-0.35 \\
(3.36)\end{array}$ & $\begin{array}{l}-0.09 \\
(0.67)\end{array}$ & $\begin{array}{l}-1.10 \\
(13.40)\end{array}$ & $\begin{array}{l}1.56 \\
(18.00)\end{array}$ & $\begin{array}{l}0.05 \\
(0.97)\end{array}$ & $\begin{array}{l}0.50 \\
(4.23)\end{array}$ \\
\hline $\begin{array}{l}\text { GOP } \\
\text { Governor }\end{array}$ & $\begin{array}{l}0.29 \\
(1.40)\end{array}$ & $\begin{array}{l}-0.64 \\
(2.53)\end{array}$ & $\begin{array}{l}0.20 \\
(0.90)\end{array}$ & $\begin{array}{l}-0.03 \\
(0.13)\end{array}$ & $\begin{array}{l}-0.09 \\
(0.60)\end{array}$ & $\begin{array}{l}0.09 \\
(0.29)\end{array}$ \\
\hline $\begin{array}{l}\text { GOP } \\
\text { Attorney } \\
\text { General }\end{array}$ & $\begin{array}{l}-0.74 \\
(2.64)\end{array}$ & $\begin{array}{l}-0.03 \\
(0.10)\end{array}$ & $\begin{array}{l}-0.64 \\
(2.14)\end{array}$ & $\begin{array}{l}0.08 \\
(0.26)\end{array}$ & $\begin{array}{l}-0.54 \\
(2.64)\end{array}$ & $\begin{array}{l}-0.59 \\
(1.34)\end{array}$ \\
\hline $\begin{array}{l}\text { (Antitrust } \\
\text { Cases - } \\
\text { Horizontal } \\
\text { Cases)/GSP }\end{array}$ & $\begin{array}{l}0.03 \\
(2.89)\end{array}$ & $\begin{array}{l}-0.03 \\
(2.46)\end{array}$ & $\begin{array}{l}-0.01 \\
(0.90)\end{array}$ & $\begin{array}{l}-0.02 \\
(1.50)\end{array}$ & $\begin{array}{l}-0.01 \\
(1.11)\end{array}$ & $\begin{array}{l}-0.04 \\
(2.34)\end{array}$ \\
\hline $\begin{array}{l}\text { (Horizontal } \\
\text { Cases)/GSP }\end{array}$ & $\begin{array}{l}0.02 \\
(0.80)\end{array}$ & $\begin{array}{l}-0.04 \\
(1.57)\end{array}$ & $\begin{array}{l}0.01 \\
(0.38)\end{array}$ & $\begin{array}{l}0.001 \\
(0.06)\end{array}$ & $\begin{array}{l}0.01 \\
(1.09)\end{array}$ & $\begin{array}{l}0.003 \\
(0.10)\end{array}$ \\
\hline $\mathrm{R}^{2}$ & 0.07 & 0.04 & 0.33 & 0.46 & 0.03 & 0.06 \\
\hline
\end{tabular}


Table 4: Horizontal and Non-horizontal Antitrust Cases

Fixed Effects Coefficients (t-statistics)

Dependent Variable=Establishment Gross Exit Rates, Small Manufacturing

\begin{tabular}{|c|c|c|c|c|c|c|}
\hline Variable & \begin{tabular}{|l} 
Manuf- \\
$1 \_19$ \\
\end{tabular} & $\begin{array}{l}\text { Manuf- } \\
1 \_19\end{array}$ & $\begin{array}{l}\text { Manuf- } \\
\text { 20_99 }\end{array}$ & $\begin{array}{l}\text { Manuf- } \\
\text { 20_99 }\end{array}$ & $\begin{array}{l}\text { Manuf- } \\
100 \_499\end{array}$ & $\begin{array}{l}\text { Manuf- } \\
100 \_499\end{array}$ \\
\hline Intercept & \begin{tabular}{|l|}
12.41 \\
$(10.92)$ \\
\end{tabular} & $\begin{array}{l}12.59 \\
(23.54)\end{array}$ & $\begin{array}{l}5.46 \\
(4.14)\end{array}$ & $\begin{array}{l}2.91 \\
(5.09)\end{array}$ & $\begin{array}{l}2.57 \\
(1.02)\end{array}$ & $\begin{array}{l}4.44 \\
(4.11)\end{array}$ \\
\hline $\begin{array}{l}\text { Entry Rate, } \\
\text { Manufacturing }\end{array}$ & - & $\begin{array}{l}-0.23 \\
(3.27) \\
\end{array}$ & - & $\begin{array}{l}0.17 \\
(2.31) \\
\end{array}$ & - & $\begin{array}{l}0.11 \\
(0.82) \\
\end{array}$ \\
\hline $\begin{array}{l}\text { Annual Rate of GSP } \\
\text { Growth }\end{array}$ & \begin{tabular}{|l|}
-0.11 \\
$(4.90)$ \\
\end{tabular} & - & $\begin{array}{l}-0.01 \\
(0.27)\end{array}$ & - & $\begin{array}{l}-0.14 \\
(2.80)\end{array}$ & - \\
\hline $\begin{array}{l}\text { Unemployment } \\
\text { Rate }\end{array}$ & \begin{tabular}{|l|}
-0.01 \\
$(0.18)$ \\
\end{tabular} & - & $\begin{array}{l}0.05 \\
(0.67)\end{array}$ & - & $\begin{array}{l}0.04 \\
(0.28)\end{array}$ & - \\
\hline $\begin{array}{l}\text { Private Sector } \\
\text { Union Coverage } \\
\text { Rate }\end{array}$ & \begin{tabular}{|l|}
0.22 \\
$(3.87)$
\end{tabular} & - & $\begin{array}{l}-0.02 \\
(0.36)\end{array}$ & - & $\begin{array}{l}0.17 \\
(1.34)\end{array}$ & - \\
\hline $\begin{array}{l}\text { \% of workers in } \\
\text { firms with over } 500 \\
\text { employees }\end{array}$ & \begin{tabular}{|l|}
-1.17 \\
$(1.61)$
\end{tabular} & 一 & $\begin{array}{l}-1.00 \\
(1.18)\end{array}$ & - & $\begin{array}{l}2.12 \\
(1.31)\end{array}$ & - \\
\hline Taxes as $\%$ of GSP & \begin{tabular}{|l|}
0.10 \\
$(0.52)$ \\
\end{tabular} & - & $\begin{array}{l}0.55 \\
(2.51) \\
\end{array}$ & - & $\begin{array}{l}-0.18 \\
(0.44) \\
\end{array}$ & - \\
\hline $\begin{array}{l}\text { Government } \\
\text { Spending as \% of } \\
\text { GSP }\end{array}$ & \begin{tabular}{|l|}
-0.20 \\
$(4.81)$
\end{tabular} & - & $\begin{array}{l}-0.16 \\
(3.32)\end{array}$ & - & $\begin{array}{l}0.07 \\
(0.77)\end{array}$ & - \\
\hline GOP Governor & \begin{tabular}{|l|}
0.14 \\
$(1.08)$
\end{tabular} & $\begin{array}{l}0.24 \\
(1.77)\end{array}$ & $\begin{array}{l}0.16 \\
(1.09)\end{array}$ & $\begin{array}{l}0.22 \\
(1.53)\end{array}$ & $\begin{array}{l}-0.33 \\
(1.17)\end{array}$ & $\begin{array}{l}-0.30 \\
(1.07)\end{array}$ \\
\hline $\begin{array}{l}\text { GOP Attorney } \\
\text { General }\end{array}$ & \begin{tabular}{|l|}
-0.39 \\
$(2.25)$ \\
\end{tabular} & $\begin{array}{l}-0.56 \\
(2.97)\end{array}$ & $\begin{array}{l}0.09 \\
(0.45)\end{array}$ & $\begin{array}{l}0.03 \\
(0.15)\end{array}$ & $\begin{array}{l}-0.69 \\
(1.81)\end{array}$ & $\begin{array}{l}-0.85 \\
(2.24)\end{array}$ \\
\hline $\begin{array}{l}\text { (Antitrust Cases - } \\
\text { Horizontal } \\
\text { Cases)/GSP }\end{array}$ & \begin{tabular}{|l|}
0.02 \\
$(3.70)$
\end{tabular} & $\begin{array}{l}0.02 \\
(2.73)\end{array}$ & $\begin{array}{l}0.010 \\
(1.26)\end{array}$ & $\begin{array}{l}0.02 \\
(2.86)\end{array}$ & $\begin{array}{l}-0.01 \\
(0.84)\end{array}$ & $\begin{array}{l}-0.01 \\
(1.02)\end{array}$ \\
\hline $\begin{array}{l}\text { (Horizontal } \\
\text { Cases)/GSP }\end{array}$ & \begin{tabular}{|l|}
-0.01 \\
$(0.57)$ \\
\end{tabular} & $\begin{array}{l}0.004 \\
(0.33)\end{array}$ & $\begin{array}{l}0.02 \\
(3.18)\end{array}$ & $\begin{array}{l}0.001 \\
(0.06)\end{array}$ & $\begin{array}{l}-0.02 \\
(0.66)\end{array}$ & $\begin{array}{l}-0.01 \\
(0.54) \\
\end{array}$ \\
\hline $\mathrm{R}^{2}$ & 0.26 & 0.07 & 0.09 & 0.04 & 0.05 & 0.02 \\
\hline
\end{tabular}


Table 5: Horizontal and Non-horizontal Antitrust Cases

Fixed Effects Coefficients (t-statistics)

Dependent Variable=Establishment Gross Exit Rates, Small Retail

\begin{tabular}{|c|c|c|c|c|c|c|}
\hline Variable & \begin{tabular}{|l|} 
Retail- \\
1_19 \\
\end{tabular} & Retail-1_19 & $\begin{array}{l}\text { Retail- } \\
20 \_99 \\
\end{array}$ & $\begin{array}{l}\text { Retail- } \\
20 \_99\end{array}$ & $\begin{array}{l}\text { Retail- } \\
100 \_499\end{array}$ & $\begin{array}{l}\text { Retail- } \\
100 \_499\end{array}$ \\
\hline Intercept & \begin{tabular}{|l|}
13.48 \\
$(13.15)$ \\
\end{tabular} & $\begin{array}{l}9.45 \\
(23.08)\end{array}$ & $\begin{array}{l}2.08 \\
(0.94) \\
\end{array}$ & $\begin{array}{l}-6.76 \\
(8.58) \\
\end{array}$ & $\begin{array}{l}3.69 \\
(1.18) \\
\end{array}$ & $\begin{array}{l}-0.81 \\
(0.65) \\
\end{array}$ \\
\hline Entry Rate, Retail & - & $\begin{array}{l}0.28 \\
(6.74)\end{array}$ & - & $\begin{array}{l}1.29 \\
(16.40)\end{array}$ & - & $\begin{array}{l}0.71 \\
(5.64)\end{array}$ \\
\hline $\begin{array}{l}\text { Annual Rate of GSP } \\
\text { Growth }\end{array}$ & \begin{tabular}{|l|}
-0.08 \\
$(3.75)$ \\
\end{tabular} & - & $\begin{array}{l}-0.24 \\
(5.41)\end{array}$ & - & $\begin{array}{l}-0.13 \\
(2.07)\end{array}$ & - \\
\hline $\begin{array}{l}\text { Unemployment } \\
\text { Rate }\end{array}$ & \begin{tabular}{|l|}
-0.13 \\
$(2.07)$ \\
\end{tabular} & - & $\begin{array}{l}-0.70 \\
(5.09) \\
\end{array}$ & - & $\begin{array}{l}-0.40 \\
(2.09) \\
\end{array}$ & - \\
\hline $\begin{array}{l}\text { Private Sector } \\
\text { Union Coverage } \\
\text { Rate }\end{array}$ & \begin{tabular}{|l|}
-0.01 \\
$(0.20)$
\end{tabular} & - & $\begin{array}{l}-0.11 \\
(1.03)\end{array}$ & - & $\begin{array}{l}-0.02 \\
(0.13)\end{array}$ & - \\
\hline $\begin{array}{l}\text { \% of workers in } \\
\text { firms with over } 500 \\
\text { employees }\end{array}$ & \begin{tabular}{|l|}
-0.37 \\
$(0.57)$
\end{tabular} & - & $\begin{array}{l}-1.74 \\
(1.22)\end{array}$ & - & $\begin{array}{l}-1.23 \\
(0.62)\end{array}$ & - \\
\hline Taxes as $\%$ of GSP & \begin{tabular}{|l|}
-0.41 \\
$(2.42)$ \\
\end{tabular} & - & $\begin{array}{l}2.23 \\
(6.05)\end{array}$ & - & $\begin{array}{l}1.51 \\
(2.91)\end{array}$ & - \\
\hline $\begin{array}{l}\text { Government } \\
\text { Spending as \% of } \\
\text { GSP }\end{array}$ & $\begin{array}{l}0.05 \\
(1.41)\end{array}$ & - & $\begin{array}{l}0.28 \\
(3.47)\end{array}$ & - & $\begin{array}{l}0.12 \\
(1.04)\end{array}$ & - \\
\hline GOP Governor & \begin{tabular}{|l|}
-0.002 \\
$(0.02)$ \\
\end{tabular} & $\begin{array}{l}0.02 \\
(0.18) \\
\end{array}$ & $\begin{array}{l}-0.19 \\
(0.77) \\
\end{array}$ & $\begin{array}{l}0.04 \\
(0.17) \\
\end{array}$ & $\begin{array}{l}-0.01 \\
(0.03) \\
\end{array}$ & $\begin{array}{l}0.15 \\
(0.45) \\
\end{array}$ \\
\hline $\begin{array}{l}\text { GOP Attorney } \\
\text { General }\end{array}$ & \begin{tabular}{|l|}
0.11 \\
$(0.69)$ \\
\end{tabular} & $\begin{array}{l}0.01 \\
(0.06) \\
\end{array}$ & $\begin{array}{l}0.04 \\
(0.12) \\
\end{array}$ & $\begin{array}{l}-0.35 \\
(1.22) \\
\end{array}$ & $\begin{array}{l}0.41 \\
(0.87) \\
\end{array}$ & $\begin{array}{l}0.17 \\
(0.37) \\
\end{array}$ \\
\hline $\begin{array}{l}\text { (Antitrust Cases - } \\
\text { Horizontal } \\
\text { Cases)/GSP }\end{array}$ & $\begin{array}{l}-0.001 \\
(0.17)\end{array}$ & $\begin{array}{l}0.003 \\
(0.59)\end{array}$ & $\begin{array}{l}0.004 \\
(0.38)\end{array}$ & $\begin{array}{l}-0.01 \\
(0.55)\end{array}$ & $\begin{array}{l}-0.05 \\
(2.91)\end{array}$ & $\begin{array}{l}-0.06 \\
(3.58)\end{array}$ \\
\hline $\begin{array}{l}\text { (Horizontal } \\
\text { Cases)/GSP }\end{array}$ & $\begin{array}{l}-0.001 \\
(0.09)\end{array}$ & $\begin{array}{l}0.000 \\
(0.02)\end{array}$ & $\begin{array}{l}-0.01 \\
(0.40)\end{array}$ & $\begin{array}{l}0.01 \\
(0.34)\end{array}$ & $\begin{array}{l}0.002 \\
(0.08)\end{array}$ & $\begin{array}{l}0.01 \\
(0.46)\end{array}$ \\
\hline $\mathrm{R}^{2}$ & 0.07 & 0.10 & 0.22 & 0.41 & 0.08 & 0.11 \\
\hline
\end{tabular}


Table 6: Horizontal and Non-horizontal Antitrust Cases

Fixed Effects Coefficients (t-statistics)

Dependent Variable=Establishment Gross Exit Rates, Small Wholesale

\begin{tabular}{|c|c|c|c|c|c|c|}
\hline Variable & $\begin{array}{l}\text { Wholesale- } \\
\text { 1_19 }\end{array}$ & $\begin{array}{l}\text { Wholesale- } \\
\text { 1_19 }\end{array}$ & $\begin{array}{l}\text { Wholesale- } \\
\text { 20_99 }\end{array}$ & $\begin{array}{l}\text { Wholesale- } \\
\text { 20_99 }\end{array}$ & $\begin{array}{l}\text { Wholesale- } \\
\text { 100_499 }\end{array}$ & $\begin{array}{l}\text { Wholesale- } \\
\text { 100_499 }\end{array}$ \\
\hline Intercept & \begin{tabular}{|l|}
12.24 \\
$(11.39)$ \\
\end{tabular} & $\begin{array}{l}9.99 \\
(23.97)\end{array}$ & $\begin{array}{l}2.27 \\
(1.18)\end{array}$ & $\begin{array}{l}-2.12 \\
(3.13) \\
\end{array}$ & $\begin{array}{l}8.56 \\
(3.51)\end{array}$ & $\begin{array}{l}1.76 \\
(1.96)\end{array}$ \\
\hline $\begin{array}{l}\text { Entry Rate, } \\
\text { Wholesale }\end{array}$ & - & $\begin{array}{l}0.12 \\
(2.50)\end{array}$ & - & $\begin{array}{l}0.82 \\
(10.61)\end{array}$ & - & $\begin{array}{l}0.48 \\
(4.71)\end{array}$ \\
\hline $\begin{array}{l}\text { Annual Rate of } \\
\text { GSP Growth }\end{array}$ & \begin{tabular}{|l|}
-0.12 \\
$(5.42)$ \\
\end{tabular} & - & $\begin{array}{l}-0.23 \\
(5.97) \\
\end{array}$ & - & $\begin{array}{l}-0.26 \\
(5.43) \\
\end{array}$ & - \\
\hline $\begin{array}{l}\text { Unemployment } \\
\text { Rate }\end{array}$ & \begin{tabular}{|l|}
-0.09 \\
$(1.43)$ \\
\end{tabular} & - & $\begin{array}{l}-0.68 \\
(5.72) \\
\end{array}$ & - & $\begin{array}{l}-0.57 \\
(3.77) \\
\end{array}$ & - \\
\hline $\begin{array}{l}\text { Private Sector } \\
\text { Union Coverage } \\
\text { Rate }\end{array}$ & $\begin{array}{l}0.17 \\
(3.24)\end{array}$ & - & $\begin{array}{l}0.11 \\
(1.11)\end{array}$ & - & $\begin{array}{l}0.03 \\
(0.24)\end{array}$ & - \\
\hline $\begin{array}{l}\% \text { of workers in } \\
\text { firms with over } \\
500 \text { employees }\end{array}$ & $\begin{array}{l}-0.32 \\
(0.46)\end{array}$ & - & $\begin{array}{l}-0.84 \\
(0.68)\end{array}$ & - & $\begin{array}{l}-0.75 \\
(0.48)\end{array}$ & - \\
\hline $\begin{array}{l}\text { Taxes as \% of } \\
\text { GSP }\end{array}$ & \begin{tabular}{|l}
0.09 \\
$(0.50)$ \\
\end{tabular} & - & $\begin{array}{l}1.56 \\
(4.84) \\
\end{array}$ & - & $\begin{array}{l}0.97 \\
(2.40) \\
\end{array}$ & - \\
\hline $\begin{array}{l}\text { Government } \\
\text { Spending as \% } \\
\text { of GSP }\end{array}$ & $\begin{array}{l}-0.15 \\
(3.81)\end{array}$ & - & $\begin{array}{l}0.14 \\
(2.01)\end{array}$ & - & $\begin{array}{l}-0.13 \\
(1.43)\end{array}$ & - \\
\hline GOP Governor & \begin{tabular}{|l|}
-0.28 \\
$(2.34)$ \\
\end{tabular} & $\begin{array}{l}-0.17 \\
(1.30) \\
\end{array}$ & $\begin{array}{l}-0.04 \\
(0.19) \\
\end{array}$ & $\begin{array}{l}0.04 \\
(0.18) \\
\end{array}$ & $\begin{array}{l}-0.26 \\
(0.95) \\
\end{array}$ & $\begin{array}{l}-0.17 \\
(0.63) \\
\end{array}$ \\
\hline $\begin{array}{l}\text { GOP Attorney } \\
\text { General }\end{array}$ & $\begin{array}{l}-0.14 \\
(0.88) \\
\end{array}$ & $\begin{array}{l}-0.41 \\
(2.31) \\
\end{array}$ & $\begin{array}{l}0.33 \\
(1.12) \\
\end{array}$ & $\begin{array}{l}-0.36 \\
(1.27) \\
\end{array}$ & $\begin{array}{l}-0.35 \\
(0.95) \\
\end{array}$ & $\begin{array}{l}-0.95 \\
(2.49) \\
\end{array}$ \\
\hline $\begin{array}{l}\text { (Antitrust Cases } \\
\text { - Horizontal } \\
\text { Cases)/GSP }\end{array}$ & $\begin{array}{l}-0.01 \\
(1.03)\end{array}$ & $\begin{array}{l}-0.01 \\
(1.65)\end{array}$ & $\begin{array}{l}0.001 \\
(0.05)\end{array}$ & $\begin{array}{l}-0.02 \\
(1.55)\end{array}$ & $\begin{array}{l}-0.01 \\
(0.90)\end{array}$ & $\begin{array}{l}-0.02 \\
(1.78)\end{array}$ \\
\hline $\begin{array}{l}\text { (Horizontal } \\
\text { Cases)/GSP }\end{array}$ & $\begin{array}{l}-0.003 \\
(0.30)\end{array}$ & $\begin{array}{l}0.01 \\
(0.52)\end{array}$ & $\begin{array}{l}-0.03 \\
(1.34)\end{array}$ & $\begin{array}{l}-0.02 \\
(1.18)\end{array}$ & $\begin{array}{l}-0.02 \\
(0.65)\end{array}$ & $\begin{array}{l}-0.01 \\
(0.34)\end{array}$ \\
\hline $\mathrm{R}^{2}$ & 0.21 & 0.04 & 0.22 & 0.23 & 0.15 & 0.07 \\
\hline
\end{tabular}


Table 7: Horizontal and Non-horizontal Antitrust Cases

Random Effects Probit Coefficients (t-statistics) Dependent Variable=Firm Level Exits, Manufacturing

\begin{tabular}{|c|c|c|c|c|}
\hline Variable & $\begin{array}{l}\text { Manufacturing - } \\
\text { small }\end{array}$ & $\begin{array}{l}\text { Manufacturing - } \\
\text { large }\end{array}$ & $\begin{array}{l}\text { Manufacturing - } \\
\text { small }\end{array}$ & $\begin{array}{l}\text { Manufacturing - } \\
\text { large }\end{array}$ \\
\hline Intercept & $\begin{array}{l}-2.991 \\
(-7.48)\end{array}$ & $\begin{array}{l}-2.110 \\
(-5.58)\end{array}$ & $\begin{array}{l}-1.634 \\
(-10.74)\end{array}$ & $\begin{array}{l}-2.308 \\
(-12.32)\end{array}$ \\
\hline Profitability & $\begin{array}{l}0.552 \\
(2.42)\end{array}$ & $\begin{array}{l}-1.535 \\
(-4.53)\end{array}$ & $\begin{array}{l}0.460 \\
(2.21)\end{array}$ & $\begin{array}{l}-1.433 \\
(-4.65)\end{array}$ \\
\hline Sales & $\begin{array}{l}0.219 \\
(0.56)\end{array}$ & $\begin{array}{l}-0.016 \\
(-2.00)\end{array}$ & $\begin{array}{l}0.273 \\
(0.78)\end{array}$ & $\begin{array}{l}-0.015 \\
(-2.13)\end{array}$ \\
\hline Entry Rate, Manufacturing & - & - & $\begin{array}{l}-0.036 \\
(-1.96)\end{array}$ & $\begin{array}{l}0.007 \\
(0.33)\end{array}$ \\
\hline $\begin{array}{l}\text { Annual Rate of GSP } \\
\text { Growth }\end{array}$ & $\begin{array}{l}-0.006 \\
(-0.48)\end{array}$ & $\begin{array}{l}-0.026 \\
(-1.74)\end{array}$ & - & - \\
\hline Unemployment Rate & $\begin{array}{l}0.014 \\
(0.42)\end{array}$ & $\begin{array}{l}-0.164 \\
(-4.28)\end{array}$ & - & - \\
\hline $\begin{array}{l}\text { Private Sector Union } \\
\text { Coverage Rate }\end{array}$ & $\begin{array}{l}-0.011 \\
(-0.99) \\
\end{array}$ & $\begin{array}{l}-0.020 \\
(-1.55) \\
\end{array}$ & - & - \\
\hline $\begin{array}{l}\% \text { of workers in firms with } \\
\text { over } 500 \text { employees }\end{array}$ & $\begin{array}{l}0.059 \\
(0.14) \\
\end{array}$ & $\begin{array}{l}-0.055 \\
(-0.14) \\
\end{array}$ & - & - \\
\hline Taxes as $\%$ of GSP & $\begin{array}{l}-0.036 \\
(-1.03)\end{array}$ & $\begin{array}{l}-0.085 \\
(-1.91)\end{array}$ & - & - \\
\hline $\begin{array}{l}\text { Government Spending as } \\
\% \text { of GSP }\end{array}$ & $\begin{array}{l}0.085 \\
(3.63)\end{array}$ & $\begin{array}{l}0.084 \\
(3.15)\end{array}$ & - & - \\
\hline GOP Governor & $\begin{array}{l}-0.106 \\
(-1.54) \\
\end{array}$ & $\begin{array}{l}0.146 \\
(2.00) \\
\end{array}$ & $\begin{array}{l}-0.159 \\
(-2.66)\end{array}$ & $\begin{array}{l}0.157 \\
(2.44)\end{array}$ \\
\hline GOP Attorney General & $\begin{array}{l}0.052 \\
(0.65) \\
\end{array}$ & $\begin{array}{l}-0.080 \\
(-0.97) \\
\end{array}$ & $\begin{array}{l}0.001 \\
(0.02) \\
\end{array}$ & $\begin{array}{l}-0.078 \\
(-1.12)\end{array}$ \\
\hline $\begin{array}{l}\text { (Antitrust Cases - } \\
\text { Horizontal Cases)/GSP }\end{array}$ & $\begin{array}{l}-0.004 \\
(-0.49)\end{array}$ & $\begin{array}{l}-0.007 \\
(-0.69) \\
\end{array}$ & $\begin{array}{l}0.002 \\
(0.22)\end{array}$ & $\begin{array}{l}-0.009 \\
(-0.94) \\
\end{array}$ \\
\hline (Horizontal Cases)/GSP & $\begin{array}{l}-0.019 \\
(-1.39) \\
\end{array}$ & $\begin{array}{l}-0.006 \\
(-0.47) \\
\end{array}$ & $\begin{array}{l}-0.017 \\
(-1.35)\end{array}$ & $\begin{array}{l}-0.007 \\
(-0.59)\end{array}$ \\
\hline Log-likelihood & -1576.9 & -1796.9 & -1586.9 & -1812.3 \\
\hline Observations & 9818 & 12897 & 9818 & 12897 \\
\hline
\end{tabular}


Table 8: Horizontal and Non-horizontal Antitrust Cases

Random Effects Probit Coefficients (t-statistics)

Dependent Variable=Firm Level Exits, Retail

\begin{tabular}{|c|c|c|c|c|}
\hline Variable & Retail - small & Retail - large & Retail - small & Retail - large \\
\hline Intercept & $\begin{array}{l}-2.687 \\
(-2.44)\end{array}$ & $\begin{array}{l}-3.138 \\
(-4.24)\end{array}$ & $\begin{array}{l}-2.503 \\
(-4.06)\end{array}$ & $\begin{array}{l}-2.371 \\
(-6.19)\end{array}$ \\
\hline Profitability & $\begin{array}{l}-1.490 \\
(-2.17) \\
\end{array}$ & $\begin{array}{l}-3.822 \\
(-6.12) \\
\end{array}$ & $\begin{array}{l}-1.183 \\
(-1.90) \\
\end{array}$ & $\begin{array}{l}-3.384 \\
(-6.48) \\
\end{array}$ \\
\hline Sales & $\begin{array}{l}-0.871 \\
(-0.76)\end{array}$ & $\begin{array}{l}-0.005 \\
(-0.83)\end{array}$ & $\begin{array}{l}-0.561 \\
(-0.54)\end{array}$ & $\begin{array}{l}-0.004 \\
(-0.62)\end{array}$ \\
\hline Entry Rate, Retail & - & - & $\begin{array}{l}0.075 \\
(1.49)\end{array}$ & $\begin{array}{l}0.035 \\
(1.09)\end{array}$ \\
\hline Annual Rate of GSP Growth & $\begin{array}{l}0.008 \\
(0.21) \\
\end{array}$ & $\begin{array}{l}-0.015 \\
(-0.60) \\
\end{array}$ & - & - \\
\hline Unemployment Rate & $\begin{array}{l}-0.191 \\
(-1.86)\end{array}$ & $\begin{array}{l}-0.119 \\
(-1.81)\end{array}$ & - & - \\
\hline $\begin{array}{l}\text { Private Sector Union Coverage } \\
\text { Rate }\end{array}$ & $\begin{array}{l}-0.029 \\
(-0.93)\end{array}$ & $\begin{array}{l}-0.071 \\
(-3.02)\end{array}$ & - & - \\
\hline $\begin{array}{l}\% \text { of workers in firms with } \\
\text { over } 500 \text { employees }\end{array}$ & $\begin{array}{l}1.267 \\
(1.06)\end{array}$ & $\begin{array}{l}1.039 \\
(1.34)\end{array}$ & - & - \\
\hline Taxes as $\%$ of GSP & $\begin{array}{l}-0.147 \\
(-1.51) \\
\end{array}$ & $\begin{array}{l}0.007 \\
(0.10)\end{array}$ & - & - \\
\hline $\begin{array}{l}\text { Government Spending as \% of } \\
\text { GSP }\end{array}$ & $\begin{array}{l}0.160 \\
(2.16)\end{array}$ & $\begin{array}{l}0.141 \\
(2.81)\end{array}$ & - & - \\
\hline GOP Governor & $\begin{array}{l}0.166 \\
(0.82)\end{array}$ & $\begin{array}{l}-0.059 \\
(-0.50)\end{array}$ & $\begin{array}{l}0.160 \\
(0.88)\end{array}$ & $\begin{array}{l}-0.065 \\
(-0.63)\end{array}$ \\
\hline GOP Attorney General & $\begin{array}{l}-0.407 \\
(-1.79)\end{array}$ & $\begin{array}{l}0.021 \\
(0.16)\end{array}$ & $\begin{array}{l}-0.279 \\
(-1.47)\end{array}$ & $\begin{array}{l}0.043 \\
(0.38)\end{array}$ \\
\hline $\begin{array}{l}\text { (Antitrust Cases - Horizontal } \\
\text { Cases)/GSP }\end{array}$ & $\begin{array}{l}-0.022 \\
(-0.95)\end{array}$ & $\begin{array}{l}-0.044 \\
(-1.76)\end{array}$ & $\begin{array}{l}-0.014 \\
(-0.53)\end{array}$ & $\begin{array}{l}-0.051 \\
(-2.13)\end{array}$ \\
\hline (Horizontal Cases)/GSP & $\begin{array}{l}-0.022 \\
(-0.60)\end{array}$ & $\begin{array}{l}0.041 \\
(2.53)\end{array}$ & $\begin{array}{l}-0.014 \\
(-0.42)\end{array}$ & $\begin{array}{l}0.045 \\
(3.08)\end{array}$ \\
\hline Log-likelihood & -216.4 & -539.6 & -221.2 & -554.1 \\
\hline Observations & 962 & 3974 & 962 & 3974 \\
\hline
\end{tabular}


Table 9: Horizontal and Non-horizontal Antitrust Cases

Random Effects Probit Coefficients (t-statistics) Dependent Variable=Firm Level Exits, Wholesale

\begin{tabular}{|c|c|c|c|c|}
\hline Variable & $\begin{array}{l}\text { Wholesale - } \\
\text { small }\end{array}$ & $\begin{array}{l}\text { Wholesale - } \\
\text { large }\end{array}$ & $\begin{array}{l}\text { Wholesale - } \\
\text { small }\end{array}$ & $\begin{array}{l}\text { Wholesale - } \\
\text { large }\end{array}$ \\
\hline Intercept & $\begin{array}{l}-3.373 \\
(-3.06)\end{array}$ & $\begin{array}{l}-1.958 \\
(-2.93)\end{array}$ & $\begin{array}{l}-1.602 \\
(-3.45)\end{array}$ & $\begin{array}{l}-3.294 \\
(-6.82)\end{array}$ \\
\hline Profitability & $\begin{array}{l}-1.766 \\
(-2.49) \\
\end{array}$ & $\begin{array}{l}-3.226 \\
(-4.65)\end{array}$ & $\begin{array}{l}-1.484 \\
(-2.48)\end{array}$ & $\begin{array}{l}-3.201 \\
(-4.60)\end{array}$ \\
\hline Sales & $\begin{array}{l}-0.683 \\
(-1.11)\end{array}$ & $\begin{array}{l}-0.019 \\
(-1.37)\end{array}$ & $\begin{array}{l}-0.575 \\
(-1.13)\end{array}$ & $\begin{array}{l}-0.020 \\
(-1.41)\end{array}$ \\
\hline Entry Rate, Wholesale & - & - & $\begin{array}{l}-0.040 \\
(-0.92)\end{array}$ & $\begin{array}{l}0.101 \\
(2.45)\end{array}$ \\
\hline Annual Rate of GSP Growth & $\begin{array}{l}0.018 \\
(0.51)\end{array}$ & $\begin{array}{l}0.050 \\
(1.81)\end{array}$ & - & - \\
\hline Unemployment Rate & $\begin{array}{l}-0.070 \\
(-0.78)\end{array}$ & $\begin{array}{l}-0.010 \\
(-0.15)\end{array}$ & - & - \\
\hline $\begin{array}{l}\text { Private Sector Union } \\
\text { Coverage Rate }\end{array}$ & $\begin{array}{l}0.069 \\
(2.12)\end{array}$ & $\begin{array}{l}-0.056 \\
(-2.27)\end{array}$ & - & - \\
\hline $\begin{array}{l}\% \text { of workers in firms with } \\
\text { over } 500 \text { employees }\end{array}$ & $\begin{array}{l}-0.598 \\
(-0.59) \\
\end{array}$ & $\begin{array}{l}-0.294 \\
(-0.37) \\
\end{array}$ & - & - \\
\hline Taxes as $\%$ of GSP & $\begin{array}{l}-0.324 \\
(-2.62) \\
\end{array}$ & $\begin{array}{l}-0.017 \\
(-0.24) \\
\end{array}$ & - & - \\
\hline $\begin{array}{l}\text { Government Spending as \% } \\
\text { of GSP }\end{array}$ & $\begin{array}{l}0.159 \\
(2.15) \\
\end{array}$ & $\begin{array}{l}0.017 \\
(0.47) \\
\end{array}$ & - & - \\
\hline GOP Governor & $\begin{array}{l}0.008 \\
(0.04)\end{array}$ & $\begin{array}{l}0.183 \\
(1.23)\end{array}$ & $\begin{array}{l}-0.062 \\
(-0.38)\end{array}$ & $\begin{array}{l}0.230 \\
(1.60)\end{array}$ \\
\hline GOP Attorney General & $\begin{array}{l}-0.003 \\
(-0.01)\end{array}$ & $\begin{array}{l}-0.001 \\
(-0.01)\end{array}$ & $\begin{array}{l}0.051 \\
(0.30)\end{array}$ & $\begin{array}{l}0.057 \\
(0.41)\end{array}$ \\
\hline $\begin{array}{l}\text { (Antitrust Cases - Horizontal } \\
\text { Cases)/GSP }\end{array}$ & $\begin{array}{l}0.033 \\
(1.28) \\
\end{array}$ & $\begin{array}{l}0.009 \\
(0.43) \\
\end{array}$ & $\begin{array}{l}0.032 \\
(1.37) \\
\end{array}$ & $\begin{array}{l}0.010 \\
(0.46)\end{array}$ \\
\hline (Horizontal Cases)/GSP & \begin{tabular}{|c|}
-0.040 \\
$(-1.06)$
\end{tabular} & $\begin{array}{l}-0.070 \\
(-2.10)\end{array}$ & $\begin{array}{l}-0.025 \\
(-0.79)\end{array}$ & $\begin{array}{c}-0.094 \\
(-2.54)\end{array}$ \\
\hline Log-likelihood & -314.8 & -375.7 & -320.9 & -380.9 \\
\hline Observations & 1706 & 3379 & 1706 & 3379 \\
\hline
\end{tabular}

